\title{
Vegetable oils derivatives as the modifiers of the lubricating properties of water
}

\author{
Marian Włodzimierz Sułek, Witold Sas, Jan Przondo \\ Technical University of Radom, Department of Chemistry, ul. Chrobrego 27, 26-600 Radom, Poland, \\ e-mail: rektorb@pr.radom.pl
}

\begin{abstract}
Water has been used as a lubricating medium in a number of applications in tribology. Its insufficient lubricating properties are modified by appropriate additives. The aim of the tribological studies presented in this paper is an application of a mixture containing triglyceride ethoxylates and partial glycerides as well as esters and a block copolymer as additives. All the components are commercially available and relatively cheap. In order to examine the aqueous solutions, two kinds of tests were carried out on a four-ball apparatus: at the fixed load - measurements of the friction coefficient and wear as a function of time and seizure tests which made it possible to determine the scuffing load $\left(\mathrm{P}_{t}\right)$, the seizure load $\left(\mathrm{P}_{\mathrm{oz}}\right)$ and the limiting pressure of seizure $\left(\mathrm{p}_{\mathrm{oz}}\right)$. Changes in the quantities measured were analyzed as a function of concentrations ranging from $0.001 \%$ to $100 \%$. In the fixed load tests the coefficient of friction decreased almost eight-fold, reaching the lowest value of 0.06 at above $0.1 \%$ concentration of the additive. Wear decreased over 3.5 -fold. In the seizure tests a relatively high efficiency of the additive package was observed at the concentration of the order of the thousandth part of one percent. The compositions reached the maximum anti-seizure capacity at the concentrations of 4 and $10 \%$. It is particularly interesting to note that the stability of the lubricating film being formed was characterized by the scuffing load. The maximum value of $\mathrm{P}_{\mathrm{t}}$ was about $4 \mathrm{kN}$ high. Summing up, on the basis of the results obtained it may be concluded that the choice of package additives was correct and it effectively modified the lubricating properties of water.
\end{abstract}

Keywords: Ecological cutting fluids, motion resistance, wear, anti-seizure properties.

Presented at VII Conference Wasteless Technologies and Waste Management in Chemical Industry and Agriculture, Międzyzdroje, 12 - 15 June, 2007.

\section{INTRODUCTION}

An important factor influencing machining is a proper selection of the cutting fluid ${ }^{1-4}$. Up to now emulsions and microemulsions have been commonly used. A new generation of cutting fluids are the real solutions of chemical substances, called synthetic cutting fluids. Compared to emulsions and microemulsions they have better durability and the microbiological stability as well as lower utilization costs. They are also dermatologically and environmentally more friendly.

A crucial problem during the preparation of synthetic cutting fluids is appropriate selection of the components. Their aqueous solutions should satisfy the criteria determined for cutting fluids, in particular, they should significantly improve water lubricity ${ }^{-8}$. The additives, under friction conditions, should form a durable lubricating film which could reduce motion resistance, wear and prevent seizure. That is why surfactants were chosen as components of the water solutions ${ }^{9-14}$. Their tribological properties were verified via tests performed using the four-ball machine.

\section{SURFACTANTS AS POTENTIAL COMPONENTS OF CUTTING FLUIDS}

The main purpose of the application of cutting fluids is heat abstraction from the friction contact zone, reduction of motion resistance and wear. The commonly used cutting fluids are: cutting oils, emulsions, microemulsions and, lately, solutions of various chemical compounds. Usually, the basic component of cutting oils is mineral, animal or vegetable oil. The main shortcoming of oils is the low specific heat which makes quick heat abstraction impossible. In the fluids of this type lubricity was improved by an introduction of sulfur and chlorine components. The compromise of good cooling and the lubricating properties between water and oils were the emulsions oil-in-water modified by various additives. These emulsions however, have serious defect - lack of stability. The significant progress in stability was achieved in microemulsions. Due to emulsifiers (which sometimes can be harmful for human organism) one can obtain an oil-phase of higher concentration (concentrates) without losing the stability of the formulation. The concentrates allowed to reduce transportation costs and made the preparation of microemulsions having the required dilution, right before use, easier.

Technical reasons - mainly endeavor to higher machining velocity, to improve the durability of the tools produced and to increase the ecological requirements inspired a search for new cutting fluids. Aqueous solutions of chemical substances turned out to be useful. Water possesses the following advantages: relatively high heat capacity, non-flammability, ecological safety and low price. The disadvantages of the use of water (also in solutions) are the following: corrosion of metals, low lubricity and the low boiling point. Therefore, additives applied to water should level the negative actions of water and also should be ecologically safe. The selection of additives is not easy, because traditional additives are not water-soluble and are often toxic. In this research surfactants were proposed as the modifiers of negative properties of water. On the basis of the tests performed ${ }^{9-12}$, one can expect that they will form on the cooperating surfaces a sufficiently durable 
film which will reduce motion resistance, wear and improve the anti-seizure properties and the quality of the surfaces worked. On the basis of the literature data and past research 5,8-12a four-compound lubricant (named PSS) was prepared. It contains: ethoxylated triglyceride, ethoxylated partial glycerides, esters and block copolymer. The main task of the additive is an improvement of the lubricating properties of water.

The research was supposed to verify the properties of solutions containing PSS in order to apply them as cutting fluids. The precise composition by weight of the additive will be produced at the end of the research. In this paper the results of tribological tests of PSS aqueous solutions in the concentration range $0.001 \%-100 \%$ will be presented.

The composition of the mixture was set experimentally. Aqueous solutions in the wide concentrations range $0.001 \%-100 \%$ were prepared by weight and the water was distilled twice.

\section{TRIBOLOGICAL TESTS}

The friction tests were performed using a four-ball machine $\mathrm{T}-02$, produced by ITeE-Radom. The friction couple - bearing balls - was made of the ŁH15 steel, accuracy class ${ }^{\mathbf{1 6}}$. The surface roughness is $\mathrm{R}_{\mathrm{a}}=0,032 \mu \mathrm{m}$ and the hardness $60-65 \mathrm{HRC}$. The methodology of the measurements and the description of the tester have already been published ${ }^{\mathbf{1 5}, \mathbf{1 6}}$. Two types of tests were conducted:

- under a constant $2 \mathrm{kN}$ load and the rotation speed of the spindle $200 \mathrm{rpm}$. The friction coefficient $(\mu)$ was measured and averaged over the 30-seconds intervals (Fig. $1 \mathrm{a}$ and $1 \mathrm{~b})$. The results shown in Fig. 2 are the averaged values from three independent series of the measurements. After each test the wear scar diameters were measured in two directions: parallel and perpendicular to the direction of the movement and the average (d) was calculated. Wear measurements were performed with the Polar reflection microscope. The values of (d) depicted in Fig. 3 are the arithmetical average from three independent measurements.

- seizure, under the linearly increasing load. The load changed from 0 to $8 \mathrm{kN}$, with the $409 \mathrm{~N} \cdot \mathrm{s}^{-1}$ speed. The rotation speed of the spindle was $500 \mathrm{rpm}$. The moment of friction $\left(\mathrm{M}_{\mathrm{T}}\right)$ changing in time was recorded (Fig. 4). On the basis of the course of $\mathrm{M}_{\mathrm{T}}(\mathrm{t})$ the scuffing load $\left(\mathrm{P}_{\mathrm{t}}\right)$ was calculated to describe the fastness of the lubricating film. The other quantity, characterizing the anti-seizure properties, was the seizure load $\left(\mathrm{P}_{\mathrm{oz}}\right)$, under which the friction moment reached $10 \mathrm{~N} \cdot \mathrm{m}$. The limiting pressure of seizure was calculated by the formula:

$p_{o z}=0.52 \frac{P_{o z}}{d^{2}}$

where $\mathrm{P}_{\mathrm{oz}}$ - seizure load, $\mathrm{d}$ - average wear scar diameter, 0.52 - coefficient describing the geometry of forces in the friction couple.

\section{Tests under constant load (Tester T 02).}

In order to assess the influence of PSS concentration on motion resistance and wear the tests under constant load were performed in the presence of solutions in the concentration range $0,001 \%-100 \%$. The typical course of the friction coefficient and temperature in the friction couple versus time, for two concentrations $0.1 \%$ and $1 \%$ is presented in Figs. 1a and 1b.

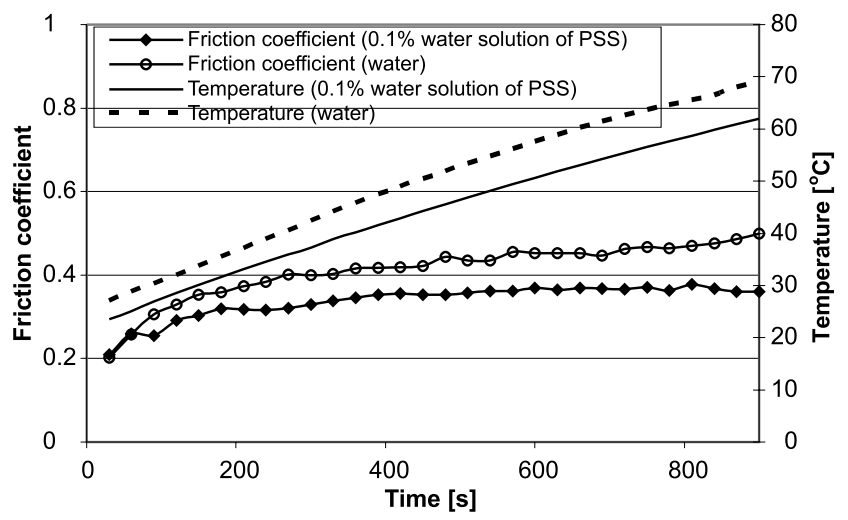

Figure 1a. Dependence of the friction coefficient and temperature in the friction couple on time (four-ball tester, load $2 \mathrm{kN}$, rotational speed of the spindle $200 \mathrm{rpm}$ )

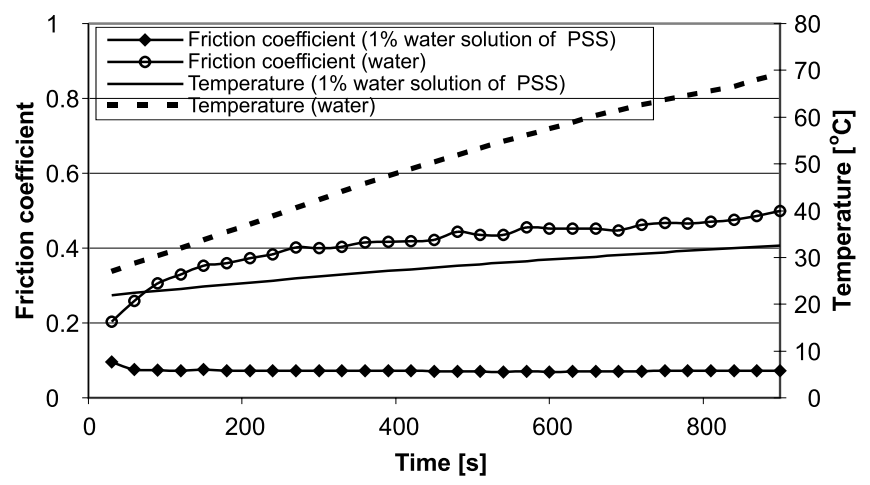

Figure 1b. Dependence of the friction coefficient and temperature in the friction couple on time (four-ball tester, load $2 \mathrm{kN}$, rotational speed of the spindle $200 \mathrm{rpm}$ )

The graphs obtained for the $0.1 \%$ solution and for the water are similar (Fig. 1a). The average $\mu$ values in the presence of all the solutions are lower by more than $20 \%$, as compared to water. Also the temperature of the lubricating medium is lower by approximately $10^{\circ} \mathrm{C}$ for aqueous solutions. Different behavior was observed at the $1 \%$ concentration. The motion resistance, as a function of time, increases in water environment, while in the solutions, during the whole test, the values of $\mu$ remain constant (Fig. 1b). Dependencies of temperature on time are also significantly different for water and its solutions. Although both runs are almost linear, for the solutions the slope of the line is considerably smaller. Consequently, the temperature after the test is more than twice higher for water, as compared to the solution.

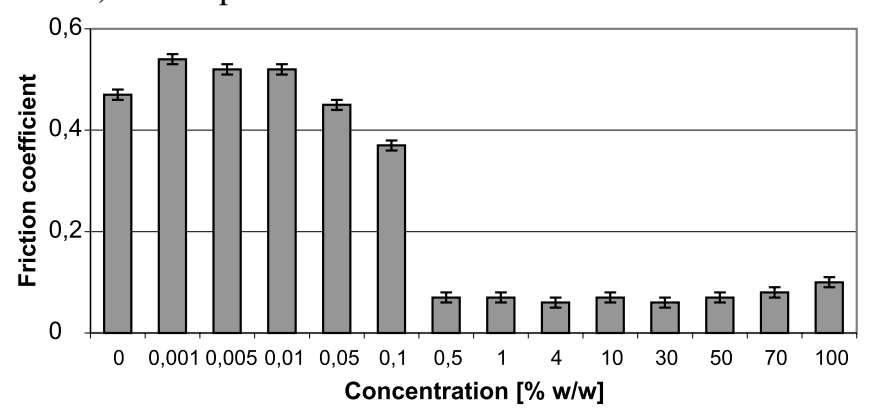

Figure 2. Dependence of the friction coefficient on PSS concentration in water solutions (four-ball tester, load $2 \mathrm{kN}$, rotational speed of the spindle 200 $\mathrm{rpm}$, friction time $900 \mathrm{~s}$ ) 
For the $0.1 \%$ concentrations and lower the friction coefficient is approximately equal to the value obtained for pure water. At lower concentrations from the interval $0.001 \%-0.01 \%$ the values of $\mu$ are in the presence of solutions even higher than for water. Above $0.01 \%$ to $0.1 \%$ one can observe a slight decrease of the quantity measured. Above $0.1 \% \mu$ rapidly decreased, for $4 \%$ the minimum was reached. The minimal value is 8 -fold smaller than the one obtained for water. Further increase of the concentration does not affect the motion resistance significantly. For the $100 \%$ solutions the value of $\mu$ is 1.7 fold larger, as compared to $4 \%$.

The wear is measured as the wear scar diameter after the test. The averages obtained in three independent measurements, for various concentrations are presented in Fig. 3. The runs of $\mu(\mathrm{t})$ and $\mathrm{d}(\mathrm{t})$ are comparable. Although, even at the $0.001 \%$ concentration the wear scar is reduced by $20 \%$, the wear is comparably high up to the concentration of $0.1 \%$. For the $0.5 \%$ solution it is reduced 3-fold. Above this concentration the wear increases uniformly, not too quickly. For the $100 \%$ solutions the wear scar diameters increases by $25 \%$. One can observe that the smallest values of $\mu$ were obtained for the $4 \%$ solution, but for other close concentrations the values are comparable in the limit of error.

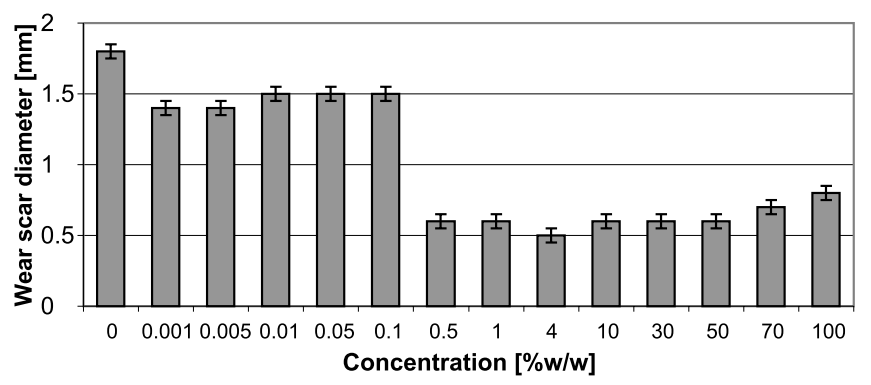

Figure 3. Dependence of the wear scar diameter on PSS concentration in water solutions (four-ball tester, load $2 \mathrm{kN}$, rotational speed of the spindle 200 $\mathrm{rpm}$, friction time $900 \mathrm{~s}$ )

\section{Anti-seizure properties.}

Effectiveness in preventing the seizure was assessed on the basis of the experimentally obtained dependence of the friction torque on the linearly increasing load (Fig. 4) and the measurements of wear scar diameters after the tests. The typical run of the friction torque $\left(\mathrm{M}_{\mathrm{T}}\right)$ versus load, for the $1 \%$ solution is shown in Fig. 4.

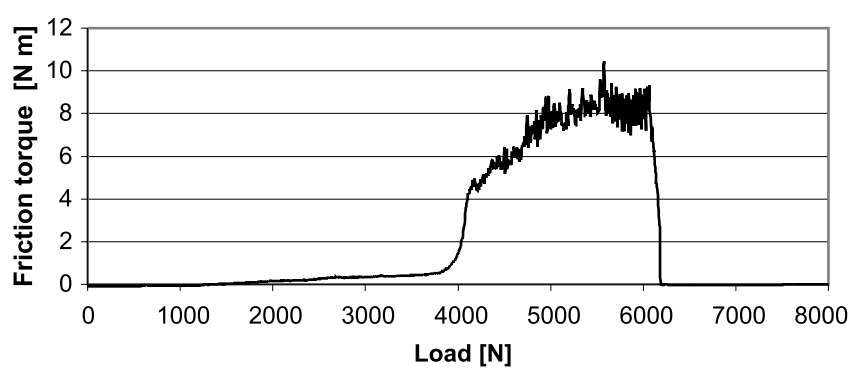

Figure 4. Dependence of the friction torque on the load for the $1 \%$ water solution of PSS (four-ball tester, rotational speed of the spindle $500 \mathrm{rpm}$, load increase rate $409 \mathrm{~N} / \mathrm{s}$ )

The first characteristic point on the graph is the one, at which a rapid increase of the friction torque occurs. It can be stated that under this load, called the scuffing load $\left(\mathrm{P}_{\mathrm{t}}\right)$, the lubricating film is torn. Above $\left(\mathrm{P}_{\mathrm{t}}\right)$ scuffing appears it lasts until the friction torque exceeds $10 \mathrm{Nm}$. The corresponding load is known as seizure load $\left(\mathrm{P}_{\mathrm{oz}}\right)$. After exceeding $\mathrm{P}_{\mathrm{oz}}$ the apparatus automatically turns off.

The scuffing load versus time is depicted in Fig. 5. The results confirm the high stability of the lubricating film obtained with the participation of the additive components. At the $0.001 \%$ concentration $P_{t}$ values are 4.5 -fold smaller as compared to pure water. The maximal value of $\mathrm{P}_{\mathrm{t}}$, reached at $1 \%$ and $4 \%$, is 19 -fold greater than for water. One can conclude that the additive remarkably modifies the insufficient lubricating properties of water. The scuffing load is comparable (or even higher) than for trade products $9,10$.

The $P_{\mathrm{oz}}$ values for solutions are greater than for water, but not so significantly as in the case of the scuffing load. For $0.001 \%$ solution $\mathrm{P}_{\mathrm{oz}}$ is 1.4 -folds greater, while the maximal value of $\mathrm{P}_{\mathrm{oz}}$ (obtained at the concentration of $4 \%$ ) is 1.7 -fold greater, as compared to water.

The runs of the limiting pressure of seizure versus concentration are analogous to the scuffing load and the seizure load. One can observe (Figs. 5, 6, 7) the presence of two local maxima: smaller, at the concentration about a few hundredth percent and the greater one, for a few percent solutions. The limiting pressure of seizure in the

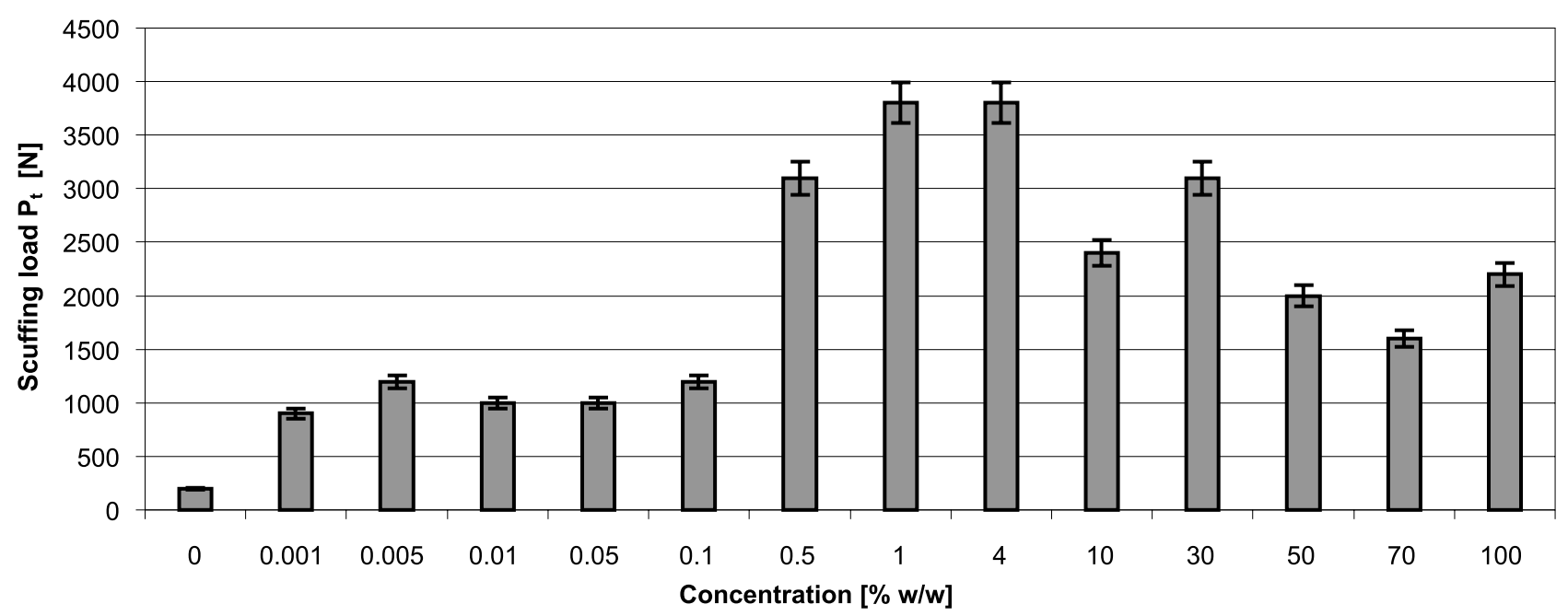

Figure 5. Dependence of the scuffing load $\left(\mathrm{P}_{\mathrm{t}}\right)$ on PSS concentration in water solutions (four-ball tester, rotational speed of the spindle $500 \mathrm{rpm}$, load increase rate $409 \mathrm{~N} / \mathrm{s}$ ) 


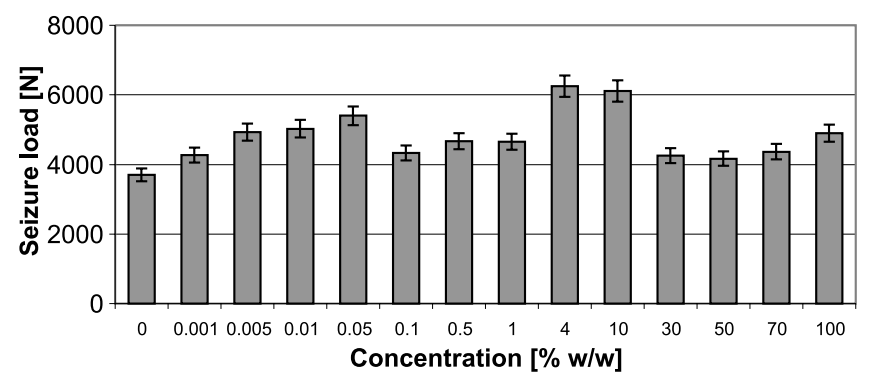

Figure 6. Dependence of the seizure load $\left(\mathrm{P}_{\mathrm{oz}}\right)$ on PSS concentration in water solutions (four-ball tester, the rotational speed of the spindle $500 \mathrm{rpm}$, load increase rate $409 \mathrm{~N} / \mathrm{s}$ )

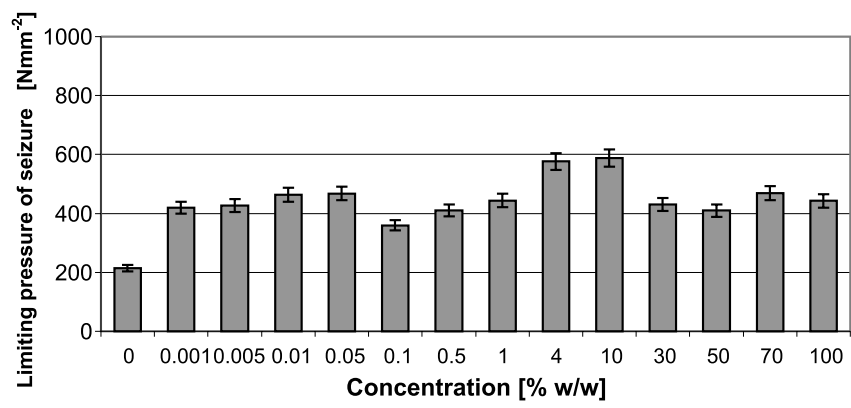

Figure 7. Dependence of the limiting pressure of seizure $\left(p_{o z}\right)$ on PSS concentration in water solutions (four-ball tester, the rotational speed of the spindle $500 \mathrm{rpm}$, load increase rate $409 \mathrm{~N} / \mathrm{s}$ )

$0.001 \%$ solution is 2 -fold and in the $10 \%$ solution $2.7-$ fold higher than for pure water.

To recapitulate: the results of the tests performed reveal that the additive efficiently improves the lubricity of water.

\section{DISCUSSION}

The results are part of the research which is supposed to define the constitution and technology of the production of real, aqueous solutions that could be applied as ecological cutting fluids. On the basis of available data an additive, which was supposed to modify the lubricity of water, was prepared. The additive consisted of 4 substances of high surface activity. The results obtained, confirmed the effectiveness of the additive in the friction zone. The additive considerably reduces motion resistance, wear (tests under constant load) and improves the anti-seizure properties (seizure tests). These favorable actions can be explained in terms of adsorptive properties in the interphase liquid-solid. The lubricating film is so durable that it cannot be destroyed up to the $4 \mathrm{kN}$ load, which is 19 -fold higher than for water. Below the scuffing $\operatorname{load}\left(\mathrm{P}_{\mathrm{t}} \approx 4 \mathrm{kN}\right)$ the compositions have perfect lubricity. Under the $2 \mathrm{kN}$ load the friction coefficient is about a few hundredth (8-fold smaller than for water) and the wear scar diameter is 3.5-fold smaller than for water. In order to correlate the adsorptive properties of the components with the tribological properties further tests will be performed. Most attention, however, will be paid to the applied research which will lead to the preparation of the composition of the new cutting fluid.

\section{LITERATURE CITED}

(1) Marzec S., Pytko S.: Tribologia procesów skrawania metali, Nowe ciecze Chłodząco-smarujące, Wyd. Biblioteka Problemów Eksplaotacji, Kraków 1999.

(2) Dąbrowski J. C., Firkowski A., Gierzyńska-Dolna M.: Ciecze obróbkowe do skrawania metali, WNT, Warszawa 1998.

(3) Michel A.: Kuhlschmierstroffe fur Hochleistungsfertigungsrefahren, Tribologie und Schmirungstechnik, 1996, 1(43), s. 7 - 13 .

(4) Weidel D.: Entsorgung von verbranchten Kuhlschmierstoffen, Tribologie und Schmirungstechnik, 1998, 3(45), s. 18 $-23$.

(5) Steinmec F.: Krajowe wodorozcieńczalne środki chłodząco-smarujące do obróbki metali skrawaniem, Nafta, 1990, 1 - 3, s. $37-41$.

(6) Luksa A.: Płyny do obróbki metali, Paliwa, Oleje i Smary w Eksploatacji, 1994, 13, s. 4 - 7.

(7) Oczoś K., Lubomow W.: Wybrane zagadnienia kształtowania powierzchni w procesach obróbkowych, Mechanik, 3/1997, s. $81-84$.

(8) Marzec S.: Physical-chemical and Tribological Phenomena in Formation of Copper Coating in Cutting Process, Zagadnienia Eksploatacji Maszyn, 2, 1998.

(9) Sułek M. W., Wasilewski T.: „Antiseizure properties of aqueous solutions of compounds forming liquid crystalline structures", Tribology Letters, 18, 2005, 197 - 205.

(10) Sułek M. W., Wasilewski T.: „Tribological properties of aqueous of alkyl polyglucosides", Wear, 260 (2006) 193 204.

(11) Sułek M. W., Bocho-Janiszewska A.: „Athoksylate des Rizinusols als Zusatse zur Modifizierung der Schmiereigenschaften von Wasser". Tribologie und Schmierungstechnik, 1, 2006.

(12) Sułek M. W., Bocho-Janiszewska A.: „The effect of ethoxylated esters on the lubricating properties of thier aqueous solutions", Tribology Letters, (24), Dec. 920060, $187-194$.

(13) Sułek M. W., Sas W., Przondo J., Wasilewski T.: „Aktywna syntetyczna baza olejowa”, Tribologia, 4/2004, (196), $237-243$.

(14) Sułek M. W., Kulczycki A., Małysa A., „Ocena jakościowa paliw na bazie biokomponentów”, Towaroznawcze Problemy Jakości, 2/2006, (7), 30 - 37.

(15) Szczerek M., Wiśniewski M.: Tribologia i Tribotechnika, Wydawnictwo ITeE, Radom 2000.

(16) Piekoszewski W., Szczerek M., Tuszyński W.: „The action of lubricans under extreme pressure ditions in amodified four-ball terster", Wear, 240, 2001, 183 - 193. 